University of Nebraska - Lincoln

DigitalCommons@University of Nebraska - Lincoln

2006

Rediscovery and Redescription of the Remarkable Phoenicus

sanguinipennis Lacordaire (Coleoptera: Cerambycidae:

Trachyderini) from the Dominican Republic

Steven Lingafelter

Systematic Entomology Laboratory, ARS, USDA National Museum of Natural History Washington, D.C. 20013-7012, U.S.A.

Eugenio Nearns

Department of Entomology and Nematology University of Florida P.O. Box 110620 Gainesville, FL

Follow this and additional works at: https://digitalcommons.unl.edu/systentomologyusda

Part of the Entomology Commons

Lingafelter, Steven and Nearns, Eugenio, "Rediscovery and Redescription of the Remarkable Phoenicus sanguinipennis Lacordaire (Coleoptera: Cerambycidae: Trachyderini) from the Dominican Republic" (2006). USDA Systematic Entomology Laboratory. 35.

https://digitalcommons.unl.edu/systentomologyusda/35

This Article is brought to you for free and open access by the Entomology Collections, Miscellaneous at DigitalCommons@University of Nebraska - Lincoln. It has been accepted for inclusion in USDA Systematic Entomology Laboratory by an authorized administrator of DigitalCommons@University of Nebraska - Lincoln. 


\title{
Rediscovery AND REDESCRIPTION OF THE REMARKABLE Phoenicus sanguinipennis Lacordaire (Coleoptera: Cerambycidae: Trachyderini) From the Dominican Republic
}

\author{
STEVen W. Lingafelter \\ Systematic Entomology Laboratory, ARS, USDA \\ National Museum of Natural History \\ Washington, D.C. 20013-7012, U.S.A. \\ AND \\ Eugenio H. Nearns \\ Department of Entomology and Nematology \\ University of Florida \\ P.O. Box 110620 \\ Gainesville, FL 32611-0620, U.S.A.
}

\begin{abstract}
Phoenicus sanguinipennis was described by Lacordaire in 1869 based on one male specimen of unknown origin. We rediscovered this species 135 years later in the Punta Cana region in La Altagracía Province of eastern Dominican Republic ( $\left.18^{\circ} 30.477^{\prime} \mathrm{N}, 68^{\circ} 22.499^{\prime} \mathrm{W}\right)$. Twentyseven specimens were collected at lights and on dead Maclura tinctoria (Linnaeus) D. Don ex Steudel (Moraceae). We provide a thorough description of the species and the previously unknown female, and a discussion of the previous and current knowledge of the species.
\end{abstract}

A remarkable, conspicuous species of longhorned woodboring beetle, Phoenicus sanguinipennis Lacordaire, previously known from only one male specimen, was rediscovered in the Dominican Republic 135 years after its initial discovery. During a survey of the Cerambycidae of the country, 27 specimens (16 males and 11 females) were found at lights and on dead Maclura tinctoria (Linnaeus) D. Don ex Steudel (Moraceae) at Punta Cana in La Altagracía Province $\left(18^{\circ} 30.477^{\prime} \mathrm{N}, 68^{\circ} 22.499^{\prime} \mathrm{W}\right)$. We provide a redescription of the species, including the first description of the female, and a discussion of its host, distribution, and an historical overview of prior knowledge of the species.

For maximum availability to the scientific community, we have distributed new material to 11 collections (5 major institutional collections and 6 private collections). Collection depository acronyms are as follows: USNM (National Museum of Natural History, Smithsonian Institution, Washington, D.C., U.S.A.); PASC (Polish Academy of Sciences Collection, Warsaw, Poland); FSCA (Florida State Collection of Arthropods, Gainesville, Florida, U.S.A.); MNRJ (Museu Nacional, Quinta da Boa Vista, Rio de Janeiro, Brazil); MZSP (Museu de Zoologia da Universidad de São Paulo, São Paulo, Brazil); MNHN (Muséum National d'Histoire Naturelle, Paris, France); ENPC (Eugenio Nearns Private Collection, Gainesville, Florida, U.S.A.); RTPC (Robert H. Turnbow, Jr. Private Collection, Ft. Rucker, Alabama, U.S.A.); FHPC (Frank T. Hovore Private Collection, Santa Clarita, California, U.S.A.); JWPC (James E. Wappes Private Collection, San Antonio, Texas, U.S.A.); RMPC (Roy F. Morris Private Collection, Lakeland, Florida, U.S.A.); DHPC (Daniel J. Heffern Private 


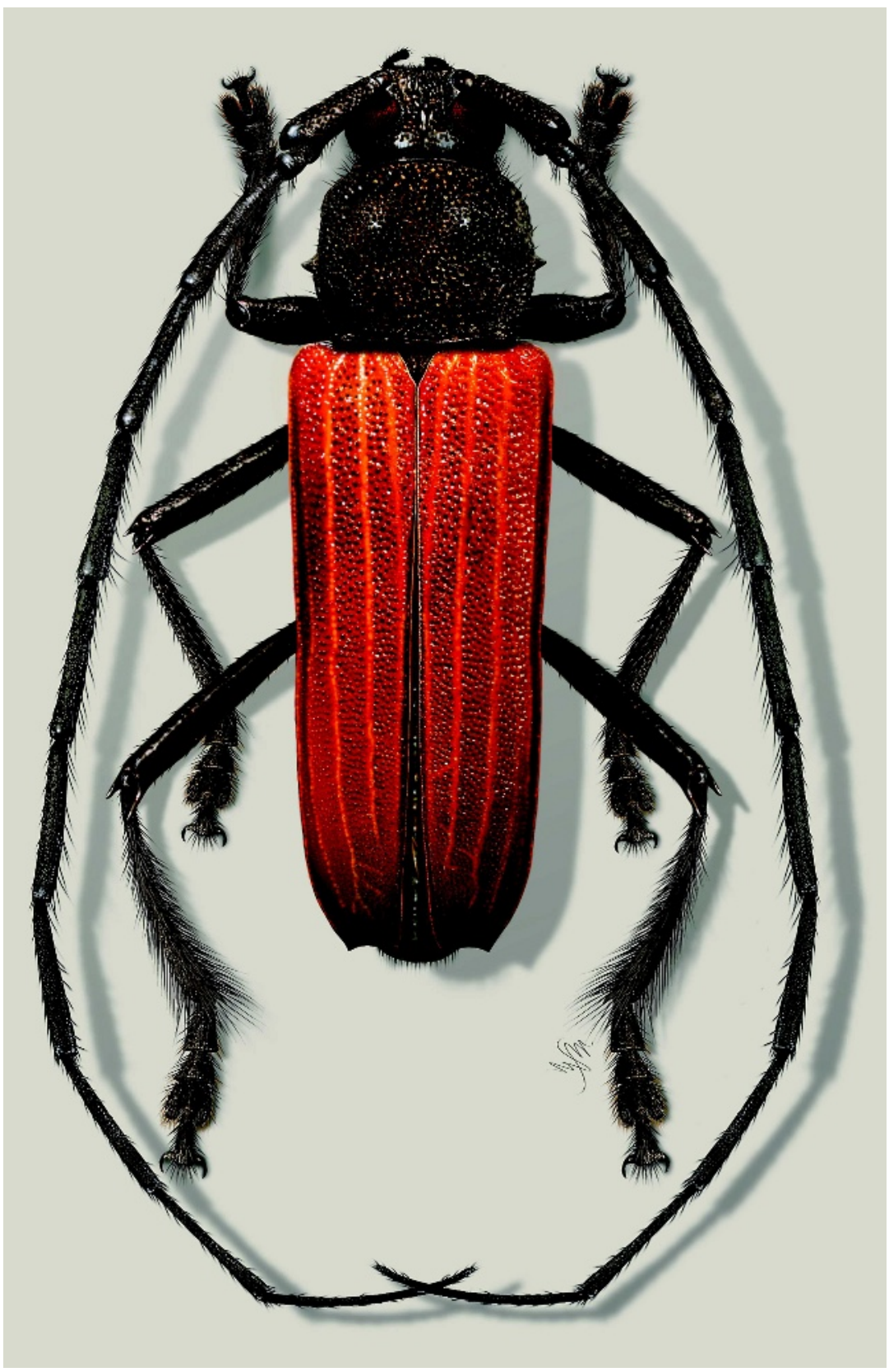

Fig. 1. Illustration of Phoenicus sanguinipennis Lacordaire (Marie Metz, illustrator). 


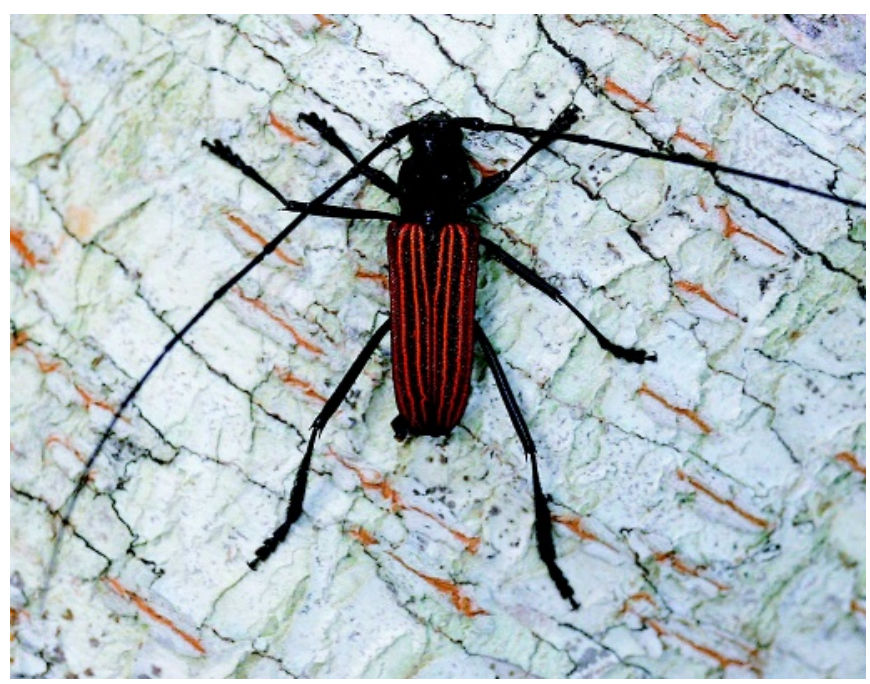

Fig. 2. Phoenicus sanguinipennis Lacordaire, live photo (Rick Stanley, photographer).

Collection, Houston, Texas); JMPC (Julio and Charyn Micheli Private Collection, Ponce, Puerto Rico, U.S.A.).

\section{Phoenicus sanguinipennis Lacordaire}

(Figs. 1-4)

Phoenicus sanguinipennis Lacordaire 1869: 174.

Redescription. Medium to large cerambycid; length $12-18 \mathrm{~mm}$ (average, $15 \mathrm{~mm}$ ); maximum width at base of elytra, 4.5-6.3 mm (average, $5.4 \mathrm{~mm}$ ). Females on average slightly longer and broader than males. Color black throughout integument except for elytron. Elytron red with three longitudinal, yellow-orange costae and transversely black at extreme apex. Head (Fig. 4b) mostly glabrous, with only a few scattered erect translucent hairs, with coarse and irregularly sized and spaced punctures, more dense on occiput, vertex, between antennal tubercles, along middle of tubercles, and along fronto-clypeal margin. Antennal tubercle weakly elevated. Eye large, finely faceted, deeply emarginated around antennal insertion, lower lobe occupying most of lateral portion of head, upper lobe smaller, about 10 ommatidial facets thick. Antenna with scape coarsely punctate, remaining segments with dense short vestiture of pubescence and weak fringe of longer hairs ventrally. Antenna of male much longer than body, extending beyond elytral apex by four segments or more, antennomeres increasing slightly in length successively from fourth through seventh, eighth through tenth subequal, eleventh 1.3 times length of tenth, weakly flattened and curved. Antenna of female shorter, extending beyond elytral apex by two to three segments, antennomeres subequal after fourth, last antennomere not flattened or curved. Pronotum (Fig. 4a) quadrate, only slightly wider than long, length 3.8$4.7 \mathrm{~mm}$ (average, $4.3 \mathrm{~mm}$ ), width $4.0-4.9 \mathrm{~mm}$ (average, $4.6 \mathrm{~mm}$ ), mostly glabrous except for inconspicuous scattered hairs as seen from lateral view. Pronotal surface densely alveolate, punctures of slightly differing shape and size, not 


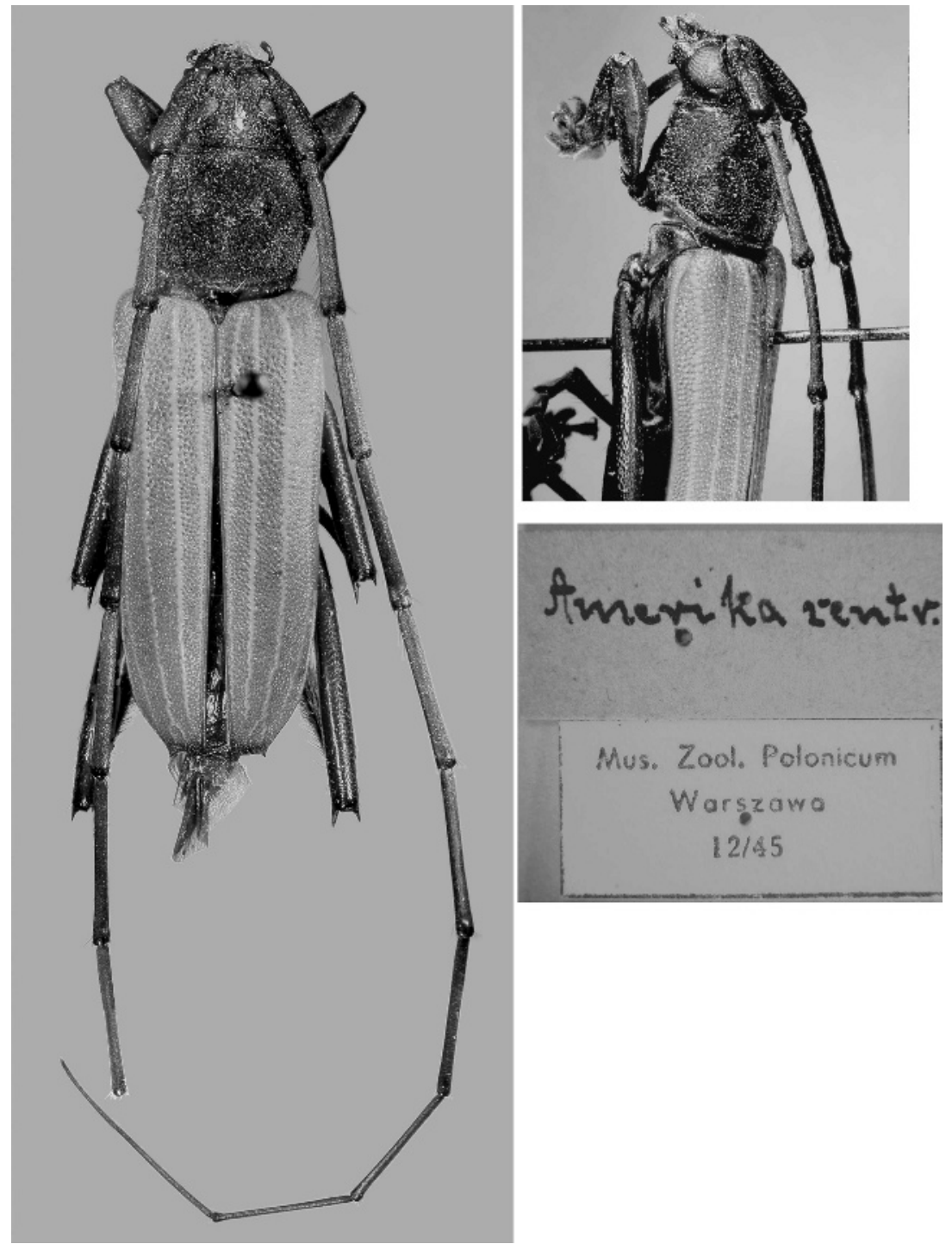

Fig. 3. Holotype of Phoenicus sanguinipennis (Polish Academy of Sciences Collection, Warsaw, Poland).

arranged in rows. Two anteromedial small, raised, impunctate calli present, and on each side, arising from just behind midpoint, a small, blunt lateral tubercle of variable size, but not extending to lateral elytral margins. Prosternum with small punctures in male and large, deep punctures in female. Prosternal process punctate, between one-third and one-half width of procoxa, with a small posteroventral tubercle and a vertical shelf to anterior border of mesosternum. 


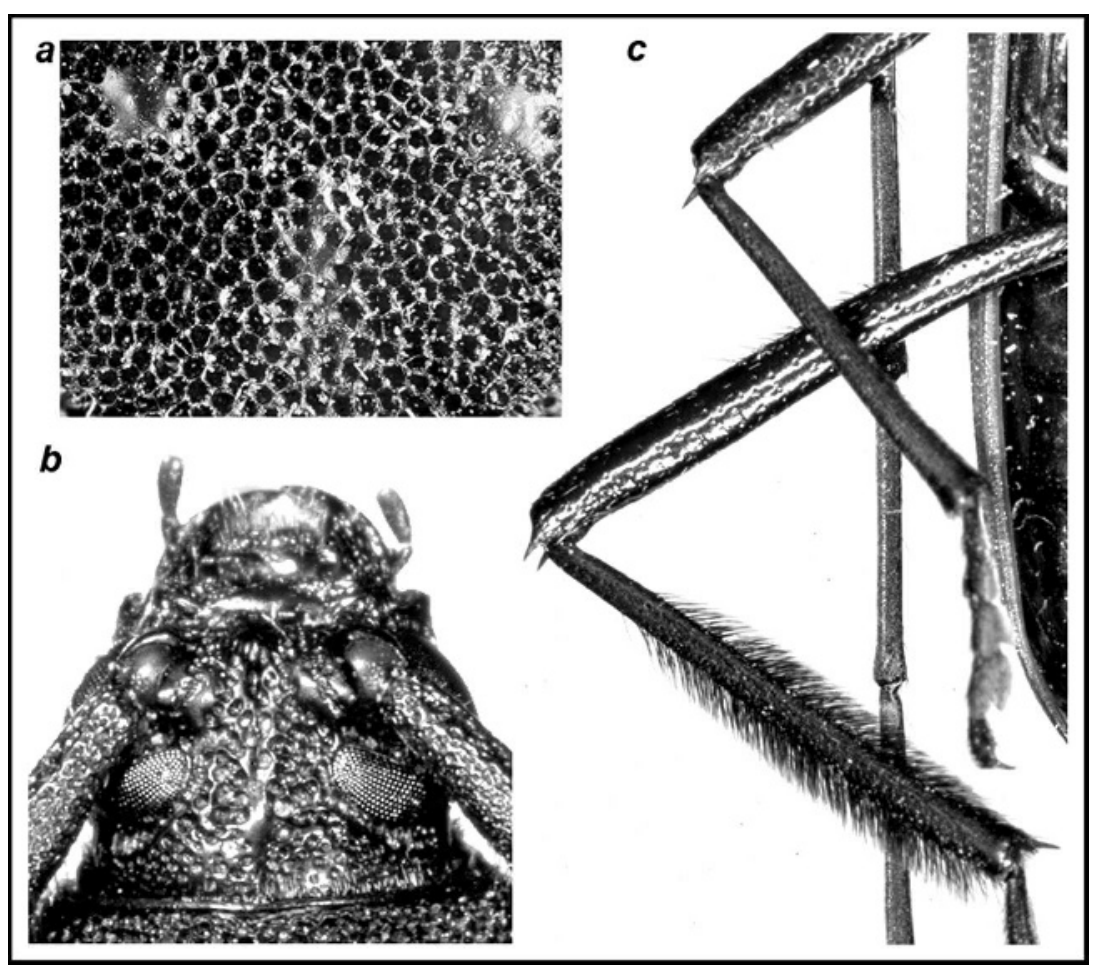

Fig. 4. Characters of Phoenicus sanguinipennis: a) pronotum detail; b) punctation of head; c) metatibial brush and femoral spines.

Procoxal cavities open laterally. Elytron nearly glabrous (except for a few scattered hairs best seen from lateral view), densely alveolate, but less so than pronotum. Punctures separated by three dorsal and one epipleural costae that extend from base to near apex (sutural costa terminates before others). In some specimens, secondary costae branch off of apices of main costae. Elytron uniformly red except for apical margin which is black and costae which are more pale orange than remainder. The bottoms of elytral punctures appear dark brown or black. Apex of elytron truncate with variably produced denticle or spine apicolaterally. Scutellum triangular, black, glabrous. Legs: foreleg stout, of average length, profemur weakly clavate, femoral apices rounded; middle leg elongate, mesofemur not clavate, mesofemoral apices spinose mesally and laterad (Fig. 4c) (mesal spines twice length of laterad spines); hind leg more elongate, hind tibia extending at or beyond elytral apex, metafemur linear, not clavate, strongly spinose femoral apices (Fig. 4c) mesally and laterad (mesal spines slightly longer than laterad spines), metatibia with very dense brush of black hairs extending around tibia from basal one-fifth to apex (Fig. 4c). Venter of metathorax and abdomen mostly glabrous, shiny, impunctate. Inconspicuous hairs on metathorax and apical ventrite. Ventrite five of male obviously wider than long; ventrite five of female elongate, obviously longer than wide. 
Diagnosis. This genus is monotypic and the only known species is very distinctive with its black and red color, alveolate punctation of the pronotum (Fig. 4a) and elytra, the pale elytral costae, the bispinose meso- and metafemoral apices (Fig. 4c), the brush of pubescence of the metatibiae (Fig. 4c), and elongate legs and antennae. No other species of Cerambycidae possess this combination of striking features. Superficially, Phoenicus sanguinipennis resembles Tragidion (particularly in the coloration, elytral costae, and metatibial brush (present in a few species of Tragidion, e.g., Tragidion cyanovestis Chemsak \& Linsley), but Tragidion species lack the meso- and metafemoral spines, have pronota with denser pubescence and finer non-alveolate punctation, and much shorter antennae in females. Rhodoleptus (in particular $R$. femoratus (Schaeffer)) is similar but the dense pubescence of the pronotum and elytron, the weaker femoral spines, less obvious costae, and absence of a metatibial brush of hairs easily distinguish it. The genus Polyschisis (in particular P. hirtipes (Olivier)) is similar in having elytral costae and pronounced metatibial pubescent brushes, but has very short antennae, not extending to apex of elytron, and lacks alveolate punctation and femoral spines. Purpuricenus has species of similar coloration, but they have reduced femoral spines, poorly developed costae, and weak or absent metatibial pubescent brushes.

Type Material. Although most Lacordaire material is deposited in the Muséum National d'Histoire Naturelle, Paris, France, Gérard Tavakilian (pers. comm.) indicated that this type is not present. It was determined that M. C. A. Dohrn material was deposited in the Stettin Museum (formerly Germany, now Poland) and transferred in the early 20th century to the collection at the Polish Academy of Sciences, Warsaw, Poland. Mieczyslaw Wolsan and Dominika Mierzwa of the Polish Academy sent two specimens of Phoenicus sanguinipennis, a male and female. Since Lacordaire based his description on only one specimen (male), this suggests that Dohrn had sent only one of the two to Lacordaire. Based on the original description, we conclude that the photographed specimen (Fig. 3) is the holotype. This specimen did not have a holotype label, but we affixed one stating, "Phoenicus sanguinipennis Lacordaire, Holotype [Male], det. Lingafelter \& Nearns 2005." Interestingly, Bates (1880) mentioned the existence of a male and female in his note on this species, so it is unclear why Lacordaire did not indicate a second specimen in his original description.

New Material. We collected 26 additional specimens of this species in 2005 and 1 specimen in 2006: Dominican Republic, La Altagracía Province, Punta Cana near Ecological Reserve, 0.5 meters, $18^{\circ} 30.477^{\prime} \mathrm{N}, 68^{\circ} 22.499^{\prime} \mathrm{W}, 29$ June, 2005, S. W. Lingafelter, attracted to lights (1 male, USNM); same, but June 30 (1 male, USNM); same but N. E. Woodley (1 female, USNM); same but 1 July, E. H. Nearns, ex: dead Maclura tinctoria [not lights] (1 male, 1 female, ENPC; 1 male, 1 female, ENPC; 1 male, RTPC; 1 male, 1 female, FHPC; 1 male, 1 female, JWPC; 1 male, 1 female, FSCA); same but S. W. Lingafelter, 2-7 July, (2 males, 2 females, USNM; 1 male, MNRJ; 1 female, MZSP; 1 male, MNHN; 1 female, DHPC; 1 male, RMPC); same but N. E. Woodley (1 male, 1 female, USNM); same but 7 July (1 male, USNM); same but 2 July 2006, at lights (1 female, USNM).

\section{Discussion}

When Jean Theodore Lacordaire received a male specimen of this species from M. C. A. Dohrn, he recognized it immediately as a new genus of Trachyderini, superficially similar to Tragidion Audinet-Serville. This specimen was collected 
from a ship that had arrived in the Port of Stettin, Poland (at that time Germany) sometime before 1869. The ship had voyaged from Central America and had cargo of "bois de teinture," or dyewood. Lacordaire (1869) described the genus and gave an overview of how it was obtained. Monné (2005) in his catalog of Cerambycinae of the Neotropical Region, indicated the uncertainty of the type locality. Since this specimen was discovered, over 135 years have elapsed and no other specimens of this very conspicuous species have been found, despite numerous intensive collecting expeditions throughout the Caribbean and Central America by many coleopterists.

The 27 specimens of this species collected during our expeditions in 2005 and 2006 were all taken adjacent to the ecological reserve at the Punta Cana Resort and Club. The first specimen was taken at a mercury vapor light along the path between the forest edge and beach on June 29. Two more specimens were taken inside a residence less than 100 yards away on the next evening. On 1 July, 10 specimens were discovered at night on a dead Maclura tinctoria tree (less than 50 feet from the mercury vapor light) that had fallen over but was partially elevated. Most of the bark was missing, but there were still some pieces loosely attached. The maximum diameter of the tree was about 10-12 inches. Specimens were mating and walking mostly on the sides and underside of the trunk, and under the loose sections of bark. Specimens were collected on the tree each evening through July 7, although the numbers declined markedly after the first night.

We did not observe oviposition, but the fact that over 20 specimens were taken on this tree, many of them in copula, suggests strongly that this is a biological host for Phoenicus sanguinipennis. In the original description, dyewood is mentioned as the cargo of the ship from which the holotype was obtained. While dyewood refers to several species of trees, one of them is, in fact, Maclura tinctoria. This tree, widely distributed in the Caribbean and Neotropical Region (Dimitri et al. 2000; Richter and Dallwitz 2000), was historically a very common source of yellow dye ("old fustic") for wool (Remington et al. 1918; Purseglove 1968), so has had an historic economic importance in commerce. Recently, biological compounds from this species of tree have shown resistance to HIV (Groweiss et al. 2000). Therefore, the discovery of an associated herbivore of this tree is significant.

Discoveries such as this, of relatively large, beautiful, conspicuous beetles in seemingly well-collected regions, highlight how little is actually known of biodiversity throughout the world. The implications of our minimal knowledge may have a practical significance in this instance, such as the very real possibility that Phoenicus sanguinipennis may sequester compounds from Maclura tinctoria that have medical importance, as studies of the host tree extracts have shown. Since the species has been unknown for 135 years, those studies, until now, could not be conceived.

\section{Acknowledgments}

We are grateful to the Kheel/Stanley Family (in particular Theodore Kheel, Jane Kheel Stanley, Rick Stanley, and Jake Kheel) for their generosity in providing accommodations at Casa de Sueños, where the specimens were collected. Thanks to Rick Stanley for the live photograph of this species and for comaraderie in the field. Thanks to Marie Metz for the color habitus illustration. Thanks to Norman Woodley for his comaraderie, for collecting part of the series, and for identifying the probable host plant. Special thanks to Miguel Monné for accurately suggesting the identity of this species. Thanks to Mieczyslaw Wolsan 
and Dominika Mierzwa (Polish Academy of Sciences) and Gérard Tavakilian (Muséum National d'Histoire Naturelle) for their efforts in locating the holotype.

\section{Literature Cited}

Bates, H. W. 1880. Biologia Centrali-Americana, Insecta, Coleoptera. London 5:17-152, pls. $3-11$.

Dimitri, M. J., R. F. J. Leonardis, and J. S. Biloni. 2000. El nuevo libro del árbol: especies forestales de la Argentina oriental. El Ateneo, Buenos Aires. 124 pp.

Groweiss, A., J. H. Cardellina, and M. R. Boyd. 2000. HIV-inhibitory xanthones and flavones from Maclura tinctoria. Journal of Natural Products 63:1537-1539.

Lacordaire, J. T. 1869. Histoire Naturelle des Insectes. Genera des Coléoptères, ou exposé méthodique et critique de tous les genres proposés jusqu'ici dans cet ordre d'insectes. Paris. Librairie Encyclopédique de Roret 9(1):1-409.

Monné, M. A. 2005. Catalogue of the Cerambycidae (Coleoptera) of the Neotropical Region. Part I. Subfamily Cerambycinae. Zootaxa 946:1-765.

Purseglove, J. W. 1968. Tropical Crops: Dicotyledons. John Wiley and Sons, Inc., New York. 719 pp.

Remington, J. P., and H. C. Wood, et al., editors. 1918. The Dispensatory of the United States of America, 20th Edition. Philadelphia: J. B. Lippincott \& Co.

Richter, H. G., and M. J. Dallwitz. 2005. Commercial timbers: descriptions, illustrations, identification, and information retrieval. In English, French, German, and Spanish. Version: 4th May 2000. http://biodiversity.uno.edu/delta/.

(Received 20 December 2005; accepted 18 March 2006. Publication date 2 November 2006.) 